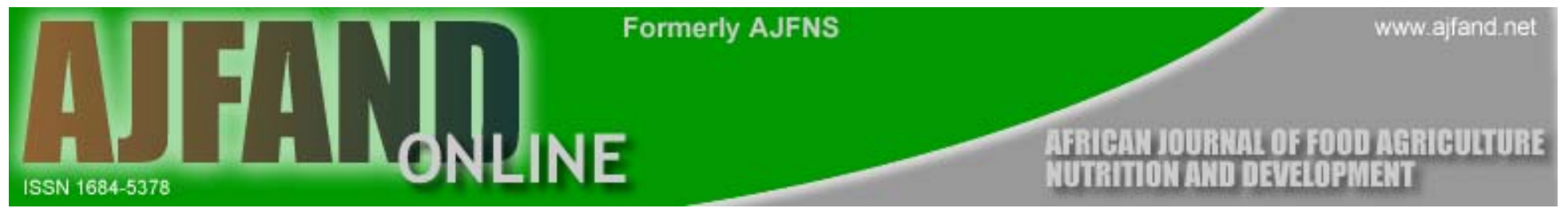

PEER REVIEWED ARTICLE No 3

\title{
PREDICTORS OF BIRTHWEIGHT IN HEALTHY WOMEN \\ ATTENDING A RURAL ANTENATAL CLINIC
}

Mathule MSL, Kennedy T, Gates G, Spicer MT*

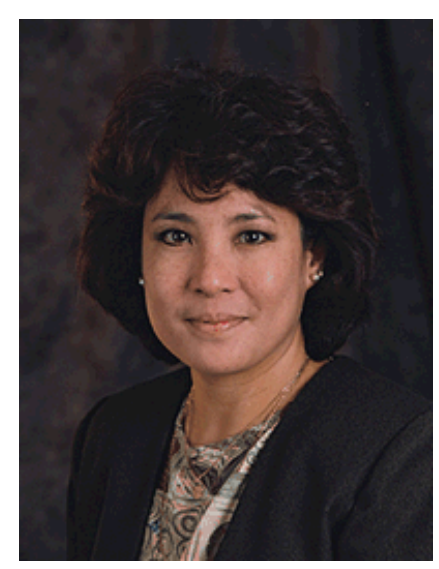

MARIA SPICER

Maria T. Spicer, Ph.D. ${ }^{1}$ email-spice@okstate.udu

* Corresponding Author 


\section{ABSTRACT}

Birthweight is important to infant survival and the later health of a child. To promote optimum birthweight, in an environment that is vulnerable to seasonal food shortages, it is important to understand the relationship between birthweight and exposure to the hungry season. The objective of this study was to determine seasonal effects on birthweight and examined the ability of maternal and seasonal variables to predict birthweight in this cohort. The study was conducted at Scott Hospital-Morija which services rural communities in Lesotho. Women with normal healthy pregnancies without complications, with a clinic attendance of five or more times, who had full term singleton infants were included. Information including infant's date of birth, infant's birthweight and length, monthly maternal weights, and date of first and last antenatal visit were systematically and retrospectively extracted from 477 Antenatal Clinic (ANC) records covering a period of three years from May 1998 to April 2001. There were 252 male infants with mean birthweight of $3169 \mathrm{~g} \pm 420$ and 225 female infants with mean birthweight of $3297 \mathrm{~g} \pm 436$. A seasonal pattern was observed with a significant difference $(p<0.05)$ between the mean birthweights in the December and January hungry season $(3100 \mathrm{~g} \pm 70)$ and the mean birthweights in March, April, August and September (3310g \pm 70$)$. First trimester exposure to the hungry season had a tendency to correlate with birthweight $(p<0.10)$. Third trimester exposure to the hungry season had a significant negative $(r=-0.106, p<0.05)$ relationship with birthweight. The best predictors of birthweight were maternal parity $(p=0.0001)$, last pregnancy weight $(p=0.0001)$ and exposure to the hungry season in the third trimester $(p=0.022)$ with the first trimester $(p=0.056)$ of pregnancy approaching significance. Thus, length of exposure to the hungry season is important in determining pregnancy outcomes. The regression model including last pregnancy weight, maternal parity and exposure to the hungry season in the third trimester explained $12.2 \%$ of the variance in birth weight $(p=0.017)$. Increased surveillance of primigravid women, promoting pregnancy weight gain for optimal infant weight at term and supplementation during the hungry season are recommended.

Key words: birthweight predictors, seasonal hunger, antenatal care

\section{FRENCH}

\section{RÉSUMÉ}

Le poids à la naissance est important pour la survie d'un bébé et pour la santé d'un enfant plus tard. Pour promouvoir un poids optimal à la naissance, dans un environnement qui est vulnérable à des carences alimentaires saisonnières, il est important de comprendre le rapport entre le poids à la naissance et le risque d'être sensible à la saison de famine. L'objectif de la présente étude était de déterminer les effets des saisons sur le poids à la naissance et d'examiner l'aptitude des variables maternelles et saisonnières à prédire le poids à la naissance dans cette cohorte. L'étude a été menée à l'hôpital Scott Hospital-Morija qui est au service des communautés rurales au Lesotho. L'étude incluait des femmes en bonne santé qui avaient eu des grossesses normales sans complications, qui s'étaient présentées à la clinique 
cinq fois ou plus, et qui avaient eu des bébés singletons tout à fait à terme. Des informations incluant la date de naissance du bébé, le poids et la longueur du bébé à la naissance, les poids de la mère chaque mois, et la date de la première et de la dernière visite prénatale ont été systématiquement et rétrospectivement extraites de 477 dossiers/registres de cliniques de consultations prénatales couvrant une période de trois ans depuis mai 1998 jusqu'en avril 2001. Il y avait 252 petits garçons ayant une moyenne du poids à la naissance de $3169 \mathrm{~g} \pm 420$ et 225 petites filles ayant une moyenne du poids à la naissance de $3297 \mathrm{~g} \pm 436$. Un modèle saisonnier a été observé avec une différence considérable $(p<0.05)$ entre les moyennes des poids à la naissance pendant la saison de famine de décembre et janvier (3100g \pm 70$)$ et les moyennes des poids à la naissance en mars, avril, août et septembre (3310g \pm 70$)$. Les trois premiers mois d'exposition à la saison de famine avaient une tendance à avoir une corrélation avec le poids à la naissance $(p<0.10)$. Le troisième trimestre d'exposition à la saison de famine avait un grand rapport négatif $(r=-0.106, p<0.05)$ avec le poids à la naissance. Les meilleurs signes précurseurs du poids à la naissance étaient la parité maternelle $(p=0.0001)$, le poids de la dernière grossesse $(p=0.0001)$ et l'exposition à la saison de famine au cours du troisième trimestre $(p=0.022)$ avec le premier trimestre $(p=0.056)$ de grossesse approchant une certaine importance. Ainsi, la longueur de l'exposition à la saison de famine est importante pour déterminer les résultats de la grossesse. Le modèle de régression incluant le poids de la dernière grossesse, la parité maternelle et l'exposition à la saison de famine au cours du troisième trimestre a expliqué $12.2 \%$ de la variance du poids à la naissance ( $p=0.017)$. Il est recommandé de surveiller davantage les femmes primigravides, promouvoir le gain pondéral pendant la grossesse en vue d'un poids optimal du bébé à terme et promouvoir la prise de suppléments aux aliments pendant la saison de famine.

Mots-clés: Signes précurseurs du poids à la naissance, famine saisonnière, soins prénataux.

\section{INTRODUCTION}

It is well recognized that birthweight is the single most important factor that determines infant and childhood morbidity and mortality [1,2]. Birthweights that range from 3500 to $4500 \mathrm{~g}$ have been associated with favorable outcomes whilst birthweights below $2500 \mathrm{~g}$ have been associated with increased episodes of diarrhea and pneumonia in children under the age of five. More recently, research also indicated that birthweight is significantly associated with early onset of stunting [3]. Birthweight as well as pregnancy weight gain are also important indicators of maternal health and nutritional status, especially in environments that are vulnerable to seasonal food shortages. Studies have demonstrated that adults, especially women, undergo seasonal body weight loss $[4,5]$.

Earlier research literature [6-9] documented that nutritional deprivation, brought about by famine during the Second World War, early in pregnancy and during the third trimester was 
associated with poor pregnancy outcomes. Several research studies [3, 10] conducted in Tropical Africa indicated that women whose third trimester of pregnancy coincided with the nutritionally debilitating season (hungry/wet season) experienced lower pregnancy weight gains and lower birthweights [11-14]. The dry season is characterized by favorable pregnancy outcomes (due to decreased maternal labor and plentiful food stocks) as evidenced by birthweights well above $3000 \mathrm{~g}$ and maternal weight gains $(>0.5 \mathrm{~kg} /$ week) that are comparable to industrialized countries. Studies conducted in developing countries showed that pregnancy weight gains are generally inadequate, averaging $6.3 \mathrm{~kg}$ for the entire pregnancy in the wet season [3]. In addition, researchers have shown that birthweight is influenced by non-seasonal factors such as increasing maternal age and parity which are associated with increased birthweight $[15,16]$.

Lesotho's food and nutrition situation is characterized by unfavorable climatic conditions contributing to food insecurity especially for the 80 to $84 \%$ of the population who live in rural areas. Food insecurity becomes more pronounced during the hungry season. Stunting amongst children under the age of five years and chronic energy deficiency in women of child bearing age are the most prevalent forms of malnutrition in the country [17]. The incidence of low birthweight in Lesotho is estimated at $11 \%$ or more of live newborns and is well above the $10 \%$ recommended by UNICEF $[17,18]$.

It is important to study the effect of season on birthweight in a temperate climate such as that in Lesotho, which has four short distinct climatic seasons which affect food production throughout the year. In this study, the hungry season was defined as the pre-harvest months of November to January. This is in contrast to tropical climates which are characterized by two seasons, the dry and wet. Finally, research that explores the effect of season on maternal nutritional status in relation to birthweight is limited in Lesotho.

\section{RESEARCH DESIGN AND METHODS}

\section{Setting}

The data were collected retrospectively from antenatal clinic records covering a period of three years (May 1998 to April 2001) at Scott Hospital in Morija. Morija is located $45 \mathrm{~km}$ south of Maseru, the capital city of Lesotho. Scott Hospital is one of the nine Christian Health Associations of Lesotho hospitals that are responsible for $45 \%$ of the health services in the country. Scott Hospital's Health Service Area covers a population of approximately 170,000 people.

\section{Sample selection}

The inclusion criterion for the study was women without pregnancy complications who attended a clinic at least five times and who delivered a full term singleton live birth. Women with pregnancy complications such as pre-eclampsia, hypertension, diabetes or multiple pregnancies as reported on the obstetric record were excluded from the study. Research literature [19] indicates that these health conditions have a confounding effect on birthweight and their control 
is thus beyond the scope of this research study. In total, $477 \mathrm{ANC}$ records were identified based on systematic sampling methodology. The ANC records were categorized first into years (19882001) and then sorted according to months of the year. After excluding records using the exclusion criteria, a random start was employed and 11 to 20 files were systematically selected from each month.

\section{Data collection}

The study variables were measurements that were routinely done in ANC clinics by trained and well experienced nurse midwives. These included last known menstrual period, expected date of delivery, infant's date of birth, infant's birthweight and length, monthly maternal weights, and date of first and last antenatal visit. Trained nursing students extracted data from the ANC records. The Ministry of Health in Lesotho and the Christian Health Association of Lesotho approved the study protocol in August 2001 and the Oklahoma State University Institutional Review Board approved the study in October 2001.

\section{Statistical analysis}

All data were analyzed by SPSS for Windows Version 10.0.5 (1999). Descriptive statistics were calculated for all 477 infant births. Analysis of variance (Sheffe Post Hoc test) and Least Squares Means were utilized to examine the differences in birthweight by month of birth. Pearson Product Moment Correlations were used to assess the relationship between birthweight, and, maternal parity, maternal age, last pregnancy weight and number of weeks during the first and third trimester of pregnancy that occurred during the hungry season. Stepwise Multiple Linear Regression was used to determine the best predictor of birthweight among the independent variables: maternal parity, last pregnancy weight and exposure to the hungry season. Exposure to hungry season was determined by calculating the number of weeks in the first and third trimester exposed to the hungry season (November to January) based on the infant's birth date (Table 1). Data is reported as means and standard deviation (SD). 


\section{RESULTS}

Figure 1 Distribution of Mean Birthweight by Month of Birth*

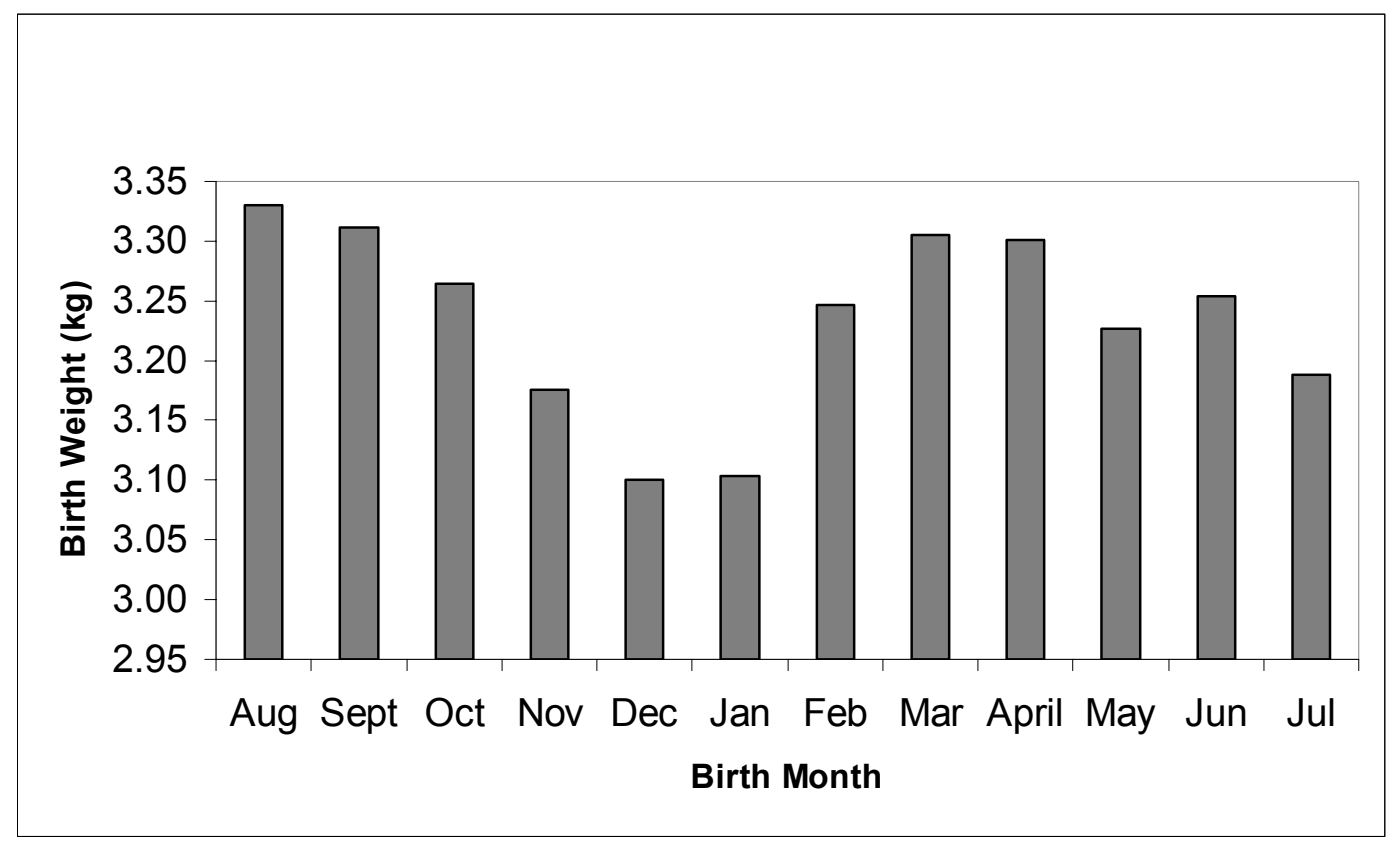

* Mean birthweights for December and January are significantly different from mean birthweights for March, April, August and September by Least Squares Means Analysis, $\mathrm{p}<0.05$.

Descriptive statistics: Data on the 477 antenatal clinic records of women who delivered singleton term infants were analyzed. There were only 25 low birthweight infants (weight less than $2,500 \mathrm{~g}$ ). The mean birthweight was $3240 \mathrm{~g} \pm 430$ and the mean birth length was $48.9 \mathrm{~cm}$ \pm 5.2 . The mean weight of the mother at last ANC visit was $74.2 \mathrm{~kg} \pm 11.6$. The average maternal parity was $2.4 \pm 1.6$ pregnancies. Maternal age was 26.8 years \pm 6.2 with an age range from 16 to 44 years. Overall, the rate of weight gain in the third trimester was computed for $95.4 \%(n=456)$ of all subjects, and showed a mean rate of weight gain of $0.386 \mathrm{~kg} /$ week \pm 0.305 . There were 252 male infants with birthweight of $3169 \mathrm{~g} \pm 420$ and 225 female infants with mean birthweight of $3297 \mathrm{~g} \pm 436$. Table 2 presents categorized descriptive data of infant birthweight by gender.

Distribution of birthweight: Figure 1 illustrates the seasonal pattern in birthweight for all subjects over the three years. The lowest birthweights were in the months of December and January during the hungry season. The higher birthweights were in March, April, August and September during the pre- and post-harvest seasons. There was no significant effect of month of birth on birthweight $(\mathrm{p}=0.2325)$. However, Least Squares Means analysis revealed a significant 
difference $(\mathrm{p}<0.05)$ between the mean birthweights in December and January $(3100 \mathrm{~g} \pm 70)$ with the mean birthweights in March, April, August and September (3310 g \pm 70$)$.

Relationship between birthweight and independent variables: Correlation analysis (Table 2 by variable) revealed a significant positive relationship between birthweight and infant's gender $(\mathrm{p}<0.005$, Table 2$)$, maternal age $(\mathrm{p}<0.0001$, Table 3$)$, parity $(\mathrm{p}<0.0001$, Table 4$)$ and last pregnancy weight $(\mathrm{p}<0.0001$, Table 5). First trimester exposure to the hungry season had a tendency to correlate with birthweight $(\mathrm{p}<0.10)$ but did not reach a significance of $\mathrm{p}<0.05$. Third trimester exposure to the hungry season had a slightly negative $(\mathrm{r}=-0.106)$ but significant $(\mathrm{p}<0.05)$ relationship with birthweight (Table 6).

Predictors of birthweight among independent variables: Table 7 summarizes the variance in birthweight attributed by each of the independent variables. The results of this analysis show that $7 \%$ of the variance can be explained by maternal parity (MP), $7 \%$ by last pregnancy weight (LPW) and $1 \%$ by number of weeks in the third trimester exposed to hungry season $\left(3^{\text {rd }}\right.$ TriWksExposed). First trimester exposure to hungry season explained less than $1 \%$ of the variance $(p=0.056)$. Rate of weight gain in the third trimester did not have a significant influence on birth weight. Multiple regression analysis using the significant variables yielded a regression model explaining $12.5 \%(\mathrm{p}=0.017)$ of the variance in birth weight $(\mathrm{BW})$ which is as follows: $\mathrm{BW}(\mathrm{kg})=2.565+[0.008(\mathrm{LPW})]+[0.057(\mathrm{MP})]-\left[0.013\left(3^{\mathrm{rd}}\right.\right.$ TriWksExposed $\left.)\right]$

Weeks in hungry season during first trimester did not add significantly to the model. Maternal parity was highly correlated with maternal age $(\mathrm{r}=0.766, \mathrm{p}<0.0001)$ and therefore age was not included in the birthweight predictor model.

\section{DISCUSSION}

\section{Birthweight}

In this study we found that the mean birthweight of $3240 \mathrm{~g} \pm 430$ was comparable to mean birthweight found in industrialized countries [20]. Furthermore, the mean birthweight in the present study was higher than the mean birthweight $(3068 \mathrm{~g} \pm 415)$ reported by Tjon et al. [21] in the remote mountain area of Matsonyane, Lesotho. We need to take into account that in this study pregnancy complications were eliminated and that the mothers in this cohort attended ANC at least five times during the studied pregnancy. Therefore, this sample does not include mothers who did not attend ANC or visited less than five times. The greatest concern is for mothers who do not attend ANC and deliver at home. 


\section{Seasonal distribution in birthweight}

In contrast with the findings of Tjon et al. [21], our study demonstrated a seasonal pattern in birthweight in which the hungry season was associated with lower mean birthweights. Tjon et al. [21] did not observe a seasonal pattern in birthweight in the remote mountain villages of Lesotho. The observed lower birthweights during the hungry season in this study are consistent with other studies. Studies by Aitkin in Sierra Leone [13] and Wendle-Ritcher in Burkina Faso [11] observed that the lowest birthweights were associated with the rice cultivation and harvesting of field crops. In Lesotho, the hungry season coincides with the harvest season which is characterized by heavy agricultural labor that could influence energy balance in pregnant mothers.

\section{Associations with birthweight}

Maternal parity and age were significantly positively associated with birthweight. Our findings are in agreement with those of the Ethiopian studies [13,14,22] where higher birthweights were associated with high parity and older age. In contrast, in Malawi Brabin et al. [23] identified that the likelihood of delivering low birthweight infants was the same between primiparae and multiparae women. It is has been well recognized that the higher the maternal parity, the higher the maternal age, and the higher the birthweight. Kramer [19] reported that pregnancy outcomes are less favorable between younger adolescents and women over the age of 35 years. In this cohort, the mothers' ages ranged from 15 to 49 years of age.

Pregnancy weight at last ANC and rate of weight gain in the seventh to ninth month of pregnancy visit have been associated with positive pregnancy outcomes in developing countries where women attend ANC in their late second and third trimester [24]. Our study showed that pregnancy weight at last ANC visit was positively associated with birthweight. However, the rate of weight gain in the third trimester was not associated with birthweight. Other researchers found that a low rate of weight gain (below $0.3 \mathrm{~kg} /$ week in late third trimester) was associated with increased risk (relative risk 1.7 to 2.5) for low birthweight babies [20]. In another study, Stein et al. [7] showed that weight gains below $0.5 \mathrm{~kg} / \mathrm{wk}$ in third trimester were associated with low birthweight.

The third trimester of pregnancy is a critical period for increased maternal tissue growth and fetal development. Moreover, it is a period vulnerable to nutritional deprivation [7,8,25,26]. Therefore, it is not surprising to observe a negative association between the numbers of weeks of exposure to the hungry season in the third trimester and birthweight. As the number of weeks of exposure to the hungry season in the third trimester increased, the birthweight decreased (Table 6). Mean birthweights during the months of November, December and January were the lowest of the 12 months (Figure 1). This is clinically significant since women who are exposed for a longer period to the hungry season in the third trimester may be vulnerable to poor pregnancy outcomes.

These results are consistent with results of previous studies in which mean birthweights 
were lower with third trimester exposure to periods of food shortages [7]. Other studies in Africa also found that third trimester exposure to the hungry season was an important determinant of low birthweight $[12,13,14,25]$.

The rate of weight gain in the third trimester is an important indicator of maternal nutritional status and often associated with positive pregnancy outcomes. In developing countries, pregnant women tend to experience a downward trend in weight gain during the latter part of the third trimester [24]. Prentice et al. [25] observed that supplementation with a groundnut biscuit and vitamin fortified drink did not make any difference in rate of weight gain during the latter part of pregnancy from week 39 to 41. Instead, weight gain declined. However, a subsequent randomized controlled trial in Gambia found that supplementation increased both weight gain and birth weight, particularly when supplementation occurred during the hungry season [27].

Kramer [19] indicated that birthweight is determined by various maternal factors and infant characteristics. Of those considered in this study, maternal weight at last ANC visit, parity and infant sex were found to be significant by Kramer. Our study also found these three variables to be significant predictors of birthweight (Table 7).

In conclusion, exposure to the hungry season had a significant negative effect on birthweight in the third trimester. Infants whose mothers were exposed to the hungry season during the first trimester most probably experienced more favorable food availability in the third trimester as demonstrated by their birthweight and maternal weight gain. Rate of weight gain did not show any relationship with birthweight. A seasonal pattern was observed in birthweight over the years. Moreover, the lowest birthweights occurred during the hungry season and during the harvest season, whilst the highest were observed during the post-harvest and the pre-harvest season.

The marginal statistical significance between the mother's exposure to hungry season during pregnancy and the subsequent newborn infant's birthweight may be attributed to a small sample size. Furthermore, this study was limited to women who were not infected with HIV/AIDS and who attended antenatal clinic at least 5 times during their pregnancy. Additional limitations include the retrospective chart review design. Measurements were taken by experienced clinic personnel, but they were not evaluated for inter-observer reliability. Additional measurements including maternal height, dietary intake and nutritional status would have provided more convincing results. Maternal height would have allowed a body mass index calculation and a more sophisticated understanding of the affect of season on maternal weight gain.

The results of this study emphasize the importance of infant birth length, maternal parity, third trimester exposure to hungry season and last pregnancy weight as valuable indicators of pregnancy outcomes, and should be included in regular monitoring system for risk assessment. Furthermore, the results of this study provide a basis for informing policy decisions on the timing and targeting of interventions to improve maternal nutrition and pregnancy outcomes responsive 
to agro climatic seasonal conditions.

Recommendations for future studies include 1) improving data collection and recording methods, 2) collecting additional data on variables such as gestational age, ponderal index, and socioeconomic status in pre-natal risk assessment, and, 3) promoting pre-natal care at the community level through Safe Motherhood Initiatives for women who do not attend antenatal clinics and incorporating the use of home-based maternal records for this purpose. Studying the impact of seasonal hunger throughout the course of pregnancy in women that do not attend antenatal clinics is highly recommended. Food intake behavior and maternal care practices are targets for a prospective community based study in an area with a high prevalence of malnutrition. 


\section{TABLES}

\section{Table 1}

Tool for the determination of Maternal/Fetal Trimester Exposure to the Hungry Season based on infant's date of birth

0

First trimester exposure to hungry season (assume that infants born between $7^{\text {th }}$ of May and $23^{\text {rd }}$ of October were conceived between $7^{\text {th }}$ of August [exposed for 1 week] and $23^{\text {rd }}$ of January [exposed for 12 weeks])

Nov Dec Jan Feb Mar Apr May Jun Jul Aug Sept Oct

Third trimester exposure to hungry season (born between $7^{\text {th }}$ of November [exposed for 1 week] and $23^{\text {rd }}$ of April [exposed for 12 weeks])

Nov Dec Jan Feb Mar Apr May Jun Jul Aug Sept Oct

Hungry Season $=$ months of November, December, January

Infants born during last week of April and October, and those born during the first week of May and November were not exposed to the hungry season in the $1^{\text {st }}$ or $3^{\text {rd }}$ trimester. 


\section{Table 2}

Descriptive summary of data by infant's gender and corresponding correlation coefficients for variable correlation with birthweight

\begin{tabular}{|c|c|c|c|c|c|c|}
\hline \multirow{2}{*}{ Variable (unit, r) } & \multicolumn{3}{|c|}{ Female } & \multicolumn{3}{|c|}{ Male } \\
\hline & $\mathrm{n}$ & mean & $\mathrm{SD}$ & $\mathrm{n}$ & mean & SD \\
\hline Birthweight (g, 0.015**) & 225 & 3168 & 420 & 252 & 3297 & 436 \\
\hline Birth length (cm, $\left.0.335^{* * *}\right)$ & 225 & 48.7 & 5.7 & 252 & 49.2 & 4.7 \\
\hline Maternal age (yrs, $0.202 * * *)$ & 225 & 26.3 & 6.15 & 252 & 27.3 & 6.4 \\
\hline Maternal parity $(\mathrm{n}, 0.267 * * *)$ & 225 & 2.25 & 1.53 & 252 & 2.54 & 1.66 \\
\hline $\begin{array}{l}\text { Last pregnancy weight }(\mathrm{kg}, \\
\left.0.268^{* * *}\right)\end{array}$ & 225 & 73.89 & 11.23 & 252 & 74.49 & 11.10 \\
\hline $\begin{array}{l}1^{\text {st }} \text { trimester exposure to } \\
\text { hungry season (wks, } 0.087^{+} \text {) }\end{array}$ & 225 & 1.84 & 3.30 & 252 & 2.15 & 3.43 \\
\hline $\begin{array}{l}3^{\text {rd }} \text { trimester exposure to } \\
\left.\text { hungry season (wks, }-0.106^{*}\right)\end{array}$ & 225 & 2.38 & 3.53 & 252 & 2.22 & 3.37 \\
\hline $\begin{array}{l}* \mathrm{p}<0.05 \\
{ }^{* *} \mathrm{p}<0.005 \\
{ }^{* * *} \mathrm{p}<0.0001 \\
{ }^{+} \mathrm{p}<0.10\end{array}$ & & & & & & \\
\hline
\end{tabular}




\section{Table 3}

Mean Birthweight by Maternal Age

\begin{tabular}{|c|ccc|}
\hline \multirow{2}{*}{$\begin{array}{c}\text { Category } \\
\text { (yrs) }\end{array}$} & \multicolumn{3}{|c|}{ Birthweight (g) } \\
\cline { 2 - 4 } & $\mathrm{n}$ & mean & SD \\
\hline $15-19$ & 59 & 3065 & 451 \\
$20-24$ & 133 & 3196 & 394 \\
$25-29$ & 135 & 3228 & 421 \\
$30-34$ & 85 & 3363 & 443 \\
$35-39$ & 50 & 3342 & 460 \\
$40-44$ & 12 & 3242 & 342 \\
$45+$ & 3 & 3413 & 729 \\
\hline
\end{tabular}




\section{Table 4}

Mean Birthweight by Maternal Parity

\begin{tabular}{|c|ccc|}
\hline \multirow{2}{*}{$\begin{array}{c}\text { Maternal Parity } \\
\text { Category }\end{array}$} & \multicolumn{3}{|c|}{ Birthweight (g) } \\
\cline { 2 - 4 } & $\mathrm{n}$ & $\mathrm{mean}$ & $\mathrm{SD}$ \\
\hline $0-1$ & 178 & 3096 & 409 \\
$2-3$ & 195 & 3267 & 396 \\
$4-5$ & 77 & 3413 & 459 \\
$5+$ & 27 & 3440 & 477 \\
\hline
\end{tabular}




\section{Table 5}

Mean Birthweight by Last Pregnancy Weight

\begin{tabular}{|c|ccc|}
\hline \multirow{2}{*}{$\begin{array}{c}\text { Last Pregnancy Weight }(\mathrm{kg}) \\
\text { Category }\end{array}$} & \multicolumn{3}{|c|}{ Birthweight $(\mathrm{g})$} \\
\cline { 2 - 4 } & $\mathrm{n}$ & Mean & $\mathrm{SD}$ \\
\hline $51-55$ & 13 & 2851 & 481 \\
$56-85$ & 379 & 3110 & 407 \\
$86+$ & 77 & 3452 & 449 \\
\hline
\end{tabular}




\section{Table 6}

Effect of number of weeks exposed to the hungry season during the first and third trimester of pregnancy on birthweight $(\mathrm{g})$

\begin{tabular}{|c|c|c|}
\hline $\begin{array}{c}\text { Number of weeks } \\
\text { exposed }\end{array}$ & $\begin{array}{l}\text { First trimester } \\
(\text { mean } \pm \text { s.d.) } \\
(\mathrm{n})\end{array}$ & $\begin{array}{l}\text { Third trimester } \\
\text { (mean } \pm \text { s.d.) } \\
\text { (n) }\end{array}$ \\
\hline 0 & $\begin{array}{c}3206 \pm 436 \\
328\end{array}$ & $\begin{array}{c}3270 \pm 432 \\
279\end{array}$ \\
\hline 1 & $\begin{array}{c}3288 \pm 337 \\
9\end{array}$ & $\begin{array}{c}3307 \pm 485 \\
24\end{array}$ \\
\hline 2 & $\begin{array}{c}3274 \pm 399 \\
7\end{array}$ & $\begin{array}{c}3019 \pm 398 \\
23\end{array}$ \\
\hline 3 & $\begin{array}{c}3171 \pm 446 \\
11\end{array}$ & $\begin{array}{c}3151 \pm 280 \\
15\end{array}$ \\
\hline 4 & $\begin{array}{c}3429 \pm 362 \\
11\end{array}$ & $\begin{array}{c}3481 \pm 499 \\
20\end{array}$ \\
\hline 5 & $\begin{array}{c}3243 \pm 337 \\
18\end{array}$ & $\begin{array}{c}3142 \pm 448 \\
22\end{array}$ \\
\hline 6 & $\begin{array}{c}3350 \pm 474 \\
12\end{array}$ & $\begin{array}{c}3140 \pm 370 \\
15\end{array}$ \\
\hline 7 & $\begin{array}{c}3255 \pm 431 \\
24\end{array}$ & $\begin{array}{c}3215 \pm 387 \\
18\end{array}$ \\
\hline 8 & $\begin{array}{c}3503 \pm 373 \\
25\end{array}$ & $\begin{array}{c}3241 \pm 504 \\
19\end{array}$ \\
\hline 9 & $\begin{array}{c}3317 \pm 444 \\
13\end{array}$ & $\begin{array}{c}3135 \pm 465 \\
15\end{array}$ \\
\hline 10 & $\begin{array}{c}3004 \pm 590 \\
5\end{array}$ & $\begin{array}{c}2970 \pm 292 \\
10\end{array}$ \\
\hline 11 & $\begin{array}{c}3290 \pm 529 \\
9\end{array}$ & $\begin{array}{c}3197 \pm 268 \\
8\end{array}$ \\
\hline 12 & $\begin{array}{c}2988 \pm 276 \\
5\end{array}$ & $\begin{array}{c}3069 \pm 276 \\
9\end{array}$ \\
\hline
\end{tabular}




\section{Table 7}

Univariate analysis of the variance in birthweight for each independent variable

\begin{tabular}{|lcccc|}
\hline Variable & $\mathrm{N}$ & R-square & $\mathrm{F}$ & \multicolumn{1}{l|}{ Sig } \\
\hline Last pregnancy weight & 477 & 0.072 & 36.65 & 0.0001 \\
Maternal parity & 477 & 0.071 & 36.54 & 0.0001 \\
$\begin{array}{l}\text { Weeks of } 3^{\text {rd }} \text { trimester in hungry } \\
\text { season }\end{array}$ & 477 & 0.011 & 5.336 & 0.022 \\
$\begin{array}{l}\text { Weeks of } 1^{\text {st }} \text { trimester in hungry } \\
\text { season }\end{array}$ & 477 & 0.008 & 3.659 & 0.056 \\
Rate of weight gain & 456 & 0.000 & 0.101 & 0.751 \\
\end{tabular}




\section{REFERENCES}

1. Onis M, Blossner $\mathbf{M}$ and $\mathbf{J}$ Villar Levels and Patterns of Intrauterine Growth Retardation in Developing Countries. Eur. J. Clin. Nutr. 1998; 52 Suppl 1: S5-S15.

2. Ashworth A Effects of Intrauterine Growth Retardation on Morbidity and Mortality in Infants and Young Children. Eur. J. Clin. Nutr. 1998; 52 Suppl 1: S34-S42.

3. Neumann CG and GG Harrison Onset and Evolution of Stunting in Infants and Children. Examples from the Human Nutrition Collaborative Research Support Program. Kenya and Egypt Studies. Eur. J. Clin. Nutr. 1994; 48 Suppl 1: S90-102.

4. Ferro-Luzzi A, Branca F and G Pastore Body Mass Index Defines the Risk of Seasonal Energy Stress in Third World. Eur. J. Clin. Nutr. 1994; 48 Suppl 3: S165S178.

5. Durnin JV, Drummand S and K Satyanarayana A Collaborative EEC Study on Seasonality and Marginal Nutrition: The Glasgow Hyderahad (South India) Study. Eur. J. Clin. Nutr. 1990; 44 Suppl 1: S19-S20.

6. Huxley RR, Lloyd I, Goldacre M, and HAW Neil Nutritional Research in World War 2: The Oxford Nutrition Survey and its Research Potential 50 Years Later. B. J. Nutr. 2000; 84: 247-251.

7. Stein AD, Ravelli ACJ and LH Lumey Famine, Third Trimester Pregnancy Weight Gain, and Intrauterine Growth: The Dutch Famine Birth Cohort Study. Hum. Biol. 1995; 67 (1): 135-144.

8. Stein $\mathbf{Z}$ and M Susser The Dutch Famine, 1944-1945, and the Reproductive Process. I. Effects on Six Indices at Birth. Pediatr. Res. 1975; 9: 70-76.

9. Stein Z and M Susser The Dutch Famine, 1944-1945, and the Reproductive Process. II. Interrelations of Caloric Rations and Six Indices at Birth. Pediatr. Res. 1975; 9: 76-83.

10. Lawrence M, Coward WA, Lawrence F, Cole TJ and RG Whitehead Fat Gain during Pregnancy in Rural African Women: The Effect of Season and Dietary Status. Am. J. Clin. Nutr. 1987; 45: 1442-1450.

11. Wendl-Richter HU Birthweight Distribution in Rural North-west Burkina Faso. Trop. Med. Int. Health. 1997; 2 (4): 404-408.

12. Kinabo J Seasonal Variation of Birthweight Distribution in Morogoro, Tanzania. E. Afr. Med. J. 1993; 70 (12): 752-755.

13. Aitkin IW Determinants of Low Birthweight among the Mendi of Sierra Leone: Implications for Medical and Socio-economic Strategies. Int. J. Gynecol. Obstet. 1990; 33: $103-109$. 
14. Banje HMA Seasonal Variations in Birthweight Distribution in Ikwiriri Village, Tanzania. J. Trop. Pediatr. 1983; 29: 50-54.

15. Feleke Y and F Enquoselassie Maternal Age, Parity and Gestational Age on the Size of the Newborn in Addis Ababa. East Afr. Med. J. 1999; 76 (8): 468-471.

16. Ali $\mathbf{M}$ and $\mathbf{S}$ Lulseged Factors Influencing Adolescent Birth Outcome. Ethiop. Med. J. 1997; 35 (1): 35-42.

17. MHSW. Ministry of Health and Social Welfare. Women's Health Survey. Lesotho Safe Motherhood Initiative (in collaboration with country team), 1995.

18. UNICEF. United Nations Children's Fund. Maternal Nutrition and Low Birthweight. Retrieved in December, 2001 from: http:/www.unicef.org/ff1/02/1.htm. 2001.

19. Kramer MS Determinants of Low Birthweight: Methodological Assessment and Metaanalysis. Bull. World Health Organ. 1987; 65 (5): 663-737.

20. Straus RS and WH Dietze Low Maternal Weight Gain in $2^{\text {nd }}$ and $3^{\text {rd }}$ Trimester Increase the Risk for IUGR. J. Nutr. 1999; 129 (5): 1-8.

21. Tjon A, Ten WET, Kusin JA and C de With Birthweight Distribution in the Mantsonyane Area: Lesotho. Trop. Geog. Med. 1986; 38: 131-136.

22. Walraven GE, Mkanje RJ, van Asten HA, van Roosmalan J, van Dongen PW and WN Dolmans The Etiology of Low Birthweight in Rural Area of Tanzania. Trop. Med. Int. Health. 1997; 2 (6): 558-567.

23. Brabin L, Verhoeff FH, Kazembe P, Brabin BJ, Chimsuku L and R Broadhead Improving Antenatal Care for Pregnant Adolescents in Southern Malawi. Acta. Obstet. Gynecol. Scand. 1998; 77 (4): 409-419.

24. WHO. World Health Organization. Maternal Anthropometry and Pregnancy Outcomes: A WHO Collaborative Project. Bull. World Health Organ. 1995; 73 Suppl: 1-89.

25. Prentice AMW, Cole TJC, Foord FA, Lamb WH and RG Whitehead Increased Birthweight after Prenatal Dietary Supplementation of Rural African Women. Am. J. Clin. Nutr. 1987; 46: 912-925.

26. Rush D Maternal Nutrition and Perinatal Survival. Nutr. Rev. 2001; 59 (10): 315-326.

27. Ceesay SM, Prentice AM, Cole TJ, Foord F, Poskitt EME, Weaver LT and RG Whitehead Effects of Birth Weight and Perinatal Mortality of Maternal Dietary Supplements in Rural Gambia: 5 Year Randomized Controlled Trial. BMJ 1997; 315: 786-790. 


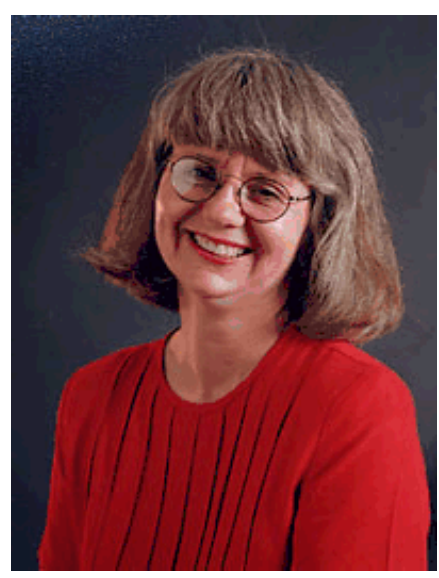

GAIL GATES

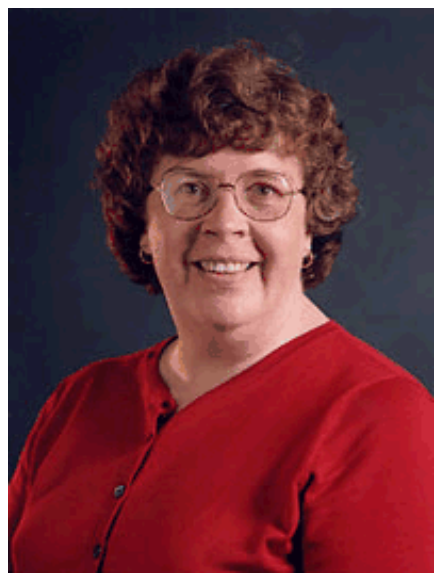

TAY KENNEDY 